Paideusis

\title{
Understanding Skills: Thinking, Feeling and Caring (Robin Barrow)
}

\section{Howard Woodhouse}

Volume 4, Number 2, 1991

URI: https://id.erudit.org/iderudit/1073382ar

DOI: https://doi.org/10.7202/1073382ar

See table of contents

Publisher(s)

Canadian Philosophy of Education Society

\section{ISSN}

0838-4517 (print)

1916-0348 (digital)

Explore this journal

Cite this document

Woodhouse, H. (1991). Understanding Skills: Thinking, Feeling and Caring (Robin Barrow). Paideusis, 4(2), 33-38. https://doi.org/10.7202/1073382ar 


\section{Review Article}

\section{Robin Barrow, Understanding Skills: Thinking, Feeling and Caring}

\section{Reviewed by Howard Woodhouse}

Barrow's most recent book is of considerable importance to educators. As its ambiguous title suggests, Understanding Skills ${ }^{1}$ is an analysis both of various kinds of intellectual skills and of understanding conceived as a capacity whose development underlies all education. Barrow argues that only where educators concern themselves with developing different kinds of understanding appropriate to the various disciplines comprising the curriculum can education enable students to grow as autonomous and rational beings who care passionately about the importance of the viewpoints and arguments they are considering $(1-2,6,178)$.

The problem, according to Barrow, is that western society has lost sight of the importance of the kind of rationality that is based on understanding. As a result, it squanders considerable resources on educational systems whose aims are to develop another kind of rationality based on generic thinking skills. Both teachers and students are misled into believing that they can become critical thinkers regardless of the context or discipline that they are thinking about (24, 88-9). Moreover, critical thinking is reduced to a set of skills conceived as discrete and repeatable exercises that can be improved by practice $(81,88)$. At no point in this process do educators attempt to increase the scope of their students' understanding because they mistakenly believe it to be quite unrelated to the skills of critical thinking. This is because they reject the notion of understanding as rooted in the disciplines traditionally taught in schools. In the recent words of Richard Herrnstein :

Cognitive skills ... apply to leaming and intellectual performance independently of subject matter...2

Barrow's objections to what he sees as this "confused and inaccurate" (1) thinking about the role of understanding in critical thinking is a major strand in the argument of his book. As a result, I shall concentrate on it, eventually levelling criticism at Barrow's own conception of critical thinking and proposing an alternative view. In this manner, I hope to convey the flavour of at least some of the book, even though its overall argument is more comprehensive and contains analysis of several other "erroneous assumptions" underlying current thinking about education. These include the belief that ideas can be understood in isolation from their historical context, that the methods of natural science are the only worthwhile methods of inquiry in education, that all values are relative, and that education must conform to the needs of the marketplace (22). In general, I find myself sympathetic to all of these criticisms of current educational theory and practice.

Barrow's views on critical thinking can best be seen in the context of an ongoing debate about its relationship to skills and to understanding. He is well aware that critical thinking requires an object of thought and a particular kind of understanding that are both discipline-related (89). Hence, any belief in critical thinking as a skill or "ability ... that is discrete and improved by training or 
practice" (88) misses the mark since it fails to appreciate that understanding, which is not reducible to a skill in this sense, is nevertheless the basis of critical thinking. It is the "erroneous categorisation" (89) that identifies critical thinking with skills alone to which Barrow objects.

The implications of this "erroneous" view are disastrous according to Barrow. As the earlier quotation from Herrnstein makes clear, they require disbanding the very disciplines that make critical thinking possible. Herrnstein himself concedes that it may be possible to make use of "a combined approach" that utilises both "thinking skills" and "the usual subjects" of the curriculum, though quite how he proposes to do this is unclear. ${ }^{3}$ In general, however, emphasis is placed in courses on critical thinking on informal and formal logic as well as on problem solving (82-7). All of these activities supposedly develop skills applicable to any discipline and to all contexts. ${ }^{4}$ In this manner, the triumph of generic skills over content is made complete and the formal ability to manipulate symbols according to the rules of logic replaces the discipline-based understanding that Barrow upholds.

It is not that Barrow is at all opposed to logic. In several places, he makes it quite clear that he strongly favours rigorous, logical argument $(6,9,80,82$, $90-1,150$ ). Rather, his objections to generic thinking skills hinge on several related points. First, taking a course in logic is neither a necessary nor a sufficient condition for thinking logically or critically. There are all sorts of people who have never taken such courses, who are quite capable of presenting arguments in a logical manner (83-4). Second, the content of informal logic courses consists of the examination of rather short passages, taken from subject matter that has little interest to the students analysing it and virtually no importance in itself (84-6). In similar fashion, problem-solving exercises are too often trivial in their content (87). Barrow does recognise, however, that these characteristics could be corrected so as to create worthwhile critical thinking programs (91). However, were this to happen, they would also have to avoid his third objection, namely, that such programs fail to recognise that some disciplines are intrinsically worth knowing and embody distinctive kinds of understanding $(86-7,149)$. It is these disciplines that should form the basis of both critical thinking programs and the curriculum in general for they comprise:

A curriculum that substantially consists of important subjects and basic and powerful forms of inquiry treated in a critical manner (91).

Nor is Barrow loath to state precisely what these disciplines are: morality, aesthetics, philosophy, mathematics, natural science, and history comprise his proposed core curriculum (87), although later in the book he adds literature and geography (149). As distinct and well-developed bodies of knowledge requiring considerable discipline and having profound consequences for human existence, Barrow considers them worthy of study by all students.

Learning the French language can be considered intrinsically worthwhile on the basis of the very criteria that Barrow lays down for the inclusion of any discipline in the core curriculum, namely, that it embody a distinctive kind of understanding that generates powerful and critical forms of inquiry $(86-7,91$, 149). In order to deny this, Barrow apparently conceives of French as a discipline in which students acquire narrow, instrumental competencies in basic linguistic structures without gaining any familiarity with the literature, 
philosophy, or culture of France or Quebec. While Barrow's fear may reflect the reality of French language classes in some schools, there is no conceptual reason for supposing that this deficiency is unavoidable. Indeed, Canada's French immersion schools continue to demonstrate quite the opposite in their development of students capable of speaking, writing, and appreciating French in the broadest of senses. ${ }^{5}$ Learning French is a particularly worthwhile activity in the context of Canada because of its fundamental importance to our literature, history, geography, philosophy, aesthetic, and moral outlooks. Since Barrow has included all of these as disciplines in his proposed core curriculum (87, 149), one can only wonder at his inconsistency in omitting French from that curriculum.

On the other hand, the inclusion of philosophy, morality, and aesthetics in the core curriculum may surprise some educators. It should be stressed that under the umbrella of aesthetics, Barrow includes both appreciation and practice of the arts, thereby ensuring the importance of art, drama, and music education, as they are usually conceived (152-3). Nor should morality seem like an unfamiliar player, since its inclusion in the Ontario curriculum, usually interwoven with other subjects, and its composition as one of the Common Essential Learnings in the Saskatchewan core curriculum, has underlined the importance of teaching and learning ethics in an increasingly secular society. Both of these examples, however, prompt the question of why Barrow seems to have opted for the teaching of ethics as a separate subject within his core curriculum. Even the discipline of philosophy has found its way into the schools in the United States, in the form of the 'Philosophy for Children' movement; in France, for far longer as a required subject for university entrance; and just last year in Ontario as a proposed high school subject in its own right. All of these developments suggest that Barrow's proposals in this regard are timely and well justified.

Yet, on analysis, his conception of philosophy seems unduly narrow. Barrow understands by philosophy simply "conceptual analysis and logical reasoning" (152). Indeed, this is all he means. In contrast, the Ontario proposal, is far broader in scope, comprising the history of Western philosophy from the Ancient Greeks, Oriental philosophy, social and political philosophy, the history and philosophy of science, epistemology, as well as the other areas that Barrow mentions: logic, aesthetics, ethics, and conceptual analysis. Why he should fail to mention any of these other important areas of philosophy is unclear. Does he think that high school students would be unable to understand them? Is conceptual analysis more important than the history of philosophy?

If Barrow really believes that philosophy should be "an integral and driving force in our educational thinking" (178), then it may be necessary to strengthen his conception of philosophy in order to make this happen. Conceptual analysis is fast being superseded by a critical approach to educational philosophy that starts from a consideration of practical educational problems, rather in the manner in which such philosophers as Dewey, Russell, and Whitehead practised their art. ${ }^{6}$ Bertrand Russell's On Education, for example, was written as a guide for parents in bringing up their children. Parts of the book also served as a basis for the curriculum and pedagogy at Beacon Hill School which he ran with Dora Russell. To say that the problems that the Russells encountered in running the school were simply the result of a lack of clarity in their ideas is only partially true. ${ }^{7}$ Yet it is just this kind of judgement 
that Barrow makes with regard to the school system today (158-9). In the case of the Russells, such a judgement overlooks the cultural, pedagogical, personal, administrative, financial, and military reasons for the school's eventual demise. To take all of these into account requires a richer philosophical framework than that of conceptual analysis. Of course, Barrow may believe that the establishment of such a framework is not a philosophical, but a historical or sociological one. The point at issue, however, is the adequacy of a philosophy that judges the truth of educational ideas solely in terms of an ideal of clarity that is both a-historical and a-contextual. For example, as an undergraduate, I can remember learning that Plato's theory of the Forms was based on a conceptual confusion about the nature of language and the ways in which general terms relate to their referents, as though I needed to know nothing about the historical context in which Platonic metaphysics was articulated. Since Barrow himself criticises his opponents for falling foul of this very fallacy (25), this indicates an important lacuna in his own thought.

All of this is particularly worrying when related to Barrow's notion of critical thinking in the core curriculum. For it is the disciplines in that curriculum that make critical thinking possible, and, where philosophy is conceived so narrowly, one wonders just how possible critical thought would be in this, or in any other discipline. Put differently, however "critically, imaginatively, and creatively" (154) one may teach, if one does so in the context of disciplines, that are so narrowly defined as to circumscribe one's activities within strict limits, then to educate the understanding of one's students may be virtually impossible. Certainly, Barrow does not intend to hamstring teachers or students in this way, but he seems oblivious to such pedagogical devices as the importance of asking questions in the process of inquiry. At no point during his critical discussion of scientific inquiry, for example, does he suggest that posing questions is, or should be, fundamental to this or any other form of inquiry. Questioning does not appear as a topic in the text, either as the foundation of scientific inquiry, or as a means to formulating a critique of the methods of science. It is similarly absent from the book's index. This comprises a major oversight on Barrow's part -- an oversight that could be corrected only by acknowledging that the search for knowledge itself is a process of asking questions. These questions may be posed of reality, of subject matter, or both. They become critical when they show that the subject matter of any discipline is unable to solve problems posed of it by reality. At this point, both reality and the subject matter become problematical and in need of revision and change. This process of critical inquiry is crucial to education in the sense that it allows a more inclusive range of experience, understanding, and action. 8

While Barrow is correct to show the importance of disciplines to critical thought, he fails to understand that critical thinking in the sense that I am using it, manages to penetrate the frameworks of meaning underlying these disciplines, and ask of them in what ways they facilitate understanding. 9 Teachers can do this by giving students frequent opportunities to ask questions so that they learn to reflect upon their own experience, understanding, and actions. This process of self-reflection requires an atmosphere of trust in which students learn to articulate their presuppositions (or frameworks of meaning) underlying their experience and understanding, even when these presuppositions may be absurd (for example, that the sun goes round the earth, or that certain races are 
genetically superior to others). Where students express presuppositions of this kind, teachers encourage them to reflect upon the justification for them. This entails getting students to question not only a set of beliefs, but an entire framework that confers meaning upon those beliefs -- in this case, the deep structures underlying pseudo-Ptolemaic or racist belief systems. The process may require reflection upon outmoded or distorted frameworks of meaning of this kind that enables students to understand their dysfunctional character. Where this takes place, students also understand that it is the frameworks of meaning underlying the various disciplines that determine what can and cannot be said in a particular type of discourse, the ways in which certain beliefs may or may not be admitted to this discourse, and the rules that determine what is to count as evidence. ${ }^{10}$ Resistance to this process often involves considerable deception on the part of those who uphold frameworks of meaning justifying racism or the belief that the earth is stationary -- a deception that may be more or less conscious. ${ }^{11}$ It is the questioning of such frameworks of meaning that makes for critical inquiry, and it is absent from the accounts of critical thinking given either by Barrow or those advocating generic thinking skills.

It should not be forgotten that on my account it is the disciplines and the underlying frameworks of meaning that make critical thinking possible. Together with their various methods of inquiry, they also provide the authority for education itself, an authority too often distorted by the influence of special interest groups upon the school system. As John McMurtry puts it:

The educational system, in short, is governed by its own disciplines of research and expression, not by special interests and demands, or it is not education. ${ }^{12}$

As a process of dispelling prejudice, conventional wisdom, and ignorance, education takes place in disciplines whose frameworks of meaning enable teachers and students alike to ask questions in an open manner. The practice of critical thinking is an established norm in these disciplines, where the authority of particular theories or individuals is considered provisional, and the disciplines provide authority for education itself.

This, then, constitutes a message of hope. Schools could become educational by allowing the disciplines they teach to be taught and learned in critical ways, consistent with their underlying frameworks of meaning. The message, however, depends upon a general acceptance of questioning as the basis of inquiry, and of critical questioning, which may entail shaking the foundations of the disciplines themselves, as the very basis of knowledge. If this were allowed, schools would be emancipated from the shackles that are currently placed upon the disciplines they teach and that too often make inquiry into a sham.

Understanding Skills contains many important insights and much sustained and elegant argument in their favour. These insights include, among others, the following: that understanding is not a skill, but a central feature of all education and differs from one discipline to another; that philosophical understanding is fundamental to learning, and hence should be included in the core curriculum and taught to all students, that generic thinking skills, thought of as a-contextual, are based on mistaken and erroneous thinking; that the claims made about generic thinking skills, particularly with regard to critical thinking, are quite unfounded; and that the basis of critical thinking is, rather, the dis- 
ciplines of the core curriculum which make such inquiry possible. The main problem with the book is that it fails to understand that critical inquiry stems from the frameworks of meaning underlying these disciplines. Seen in this way, the disciplines themselves can potentially give rise to their own critique, and they are no longer simply bodies of knowledge that are beyond question. At times, Barrow himself suggests that this may be the case. For example, he writes that, in familiarising students with the distinctive subject matter of history, the aim is to develop in them a sense of the norms of historical inquiry (181). For much of the book, however, he avoids discussion of the kind of questioning required to make this process come alive.

\section{Notes}

${ }^{1}$ Robin Barrow, Understanding Skills: Thinking, Feeling and Caring (London, Ontario: The Althouse Press, 1989).

${ }^{2}$ R.J. Herrnstein, R.S. Nickerson, M. de Sanchez, and J.A. Swets, "Teaching Thinking Skills," American Psychologist, 14(11), 1986, 1279.

${ }^{3}$ Herrnstein et al., op. cit., 1289.

${ }^{4}$ Philip H. Winne, "Intelligence and Thinking Skills," Interchange, 20(3), 1989, 39-52; and the reply by McPeck, Martin, and Sanders, "More Aerobics for the Mind?" Interchange, 20(3), 1989, 53-57.

${ }^{5}$ Sharon Lapkin and Merrill Swain, "French Immersion Research Agenda for the 1990s" (Toronto: Modern Language Centre, OISE, December 1989).

"See, for example, Brian Hendley, Dewey, Russell, Whitehead: Philosophers as Educators (Carbondale and Edwardsville: Southern Illinois University Press, 1986).

${ }^{7}$ Howard Woodhouse, "Repression in Bertrand Russell's On Education," Proceedings of the Bertrand Russell Society (Chicago: University of Chicago, January 1979).

8John McMurtry, "The History of Inquiry and Social Reproduction: Educating for Critical Thought," Interchange, 19(1), 1988, 39.

${ }^{9} \mathrm{John}$ McMurtry, "The Unspeakable: Understanding the System of Fallacy in the Media," Informal Logic, 10(3), 1988, 133-150.

${ }^{10}$ Ibid., 133, 145.

${ }^{11}$ Ian Winchester, "On Disciplines" Interchange, 17(2), 1986, 184.

${ }^{12}$ McMurtry, "The History," op. cit., 41. 